\title{
KEDUDUKAN KPK DALAM SISTEM KETATANEGARAAN DALAM PERSPEKTIF TEORI THE NEW SEPARATION OF POWER (KRITIK ATAS PUTUSAN MAHKAMAH KONSTITUSI No. 36/PUU-XV/2017 dan No. 40/PUU-XV/2017) \\ Ismail Aris \\ STAI AL-GAZALI BONE \\ Email: ismail.aris239@gmail.com
}

\begin{abstract}
The position of corruption eradication commision perspectives of new theory of Separation of powers, in fact in the constitutional system shows the Corruption Eradication Commission as an independent organ and can no longer be seated as an executive body, and is no longer relevant to classify a state institution on 3 (three) branches of power an sich, trias politica. In the above verses can re-run the power and authority of the previous institution on the executive family and diverted into quasi-judicial and quasi-legislative powers. Thus, it is no longer true that the argument that placed the Anti-Corruption Commission as an executive based on executive logic by looking at its judicial duties and functions.
\end{abstract}

Keyword: Corruption Eradication Commision, constitutional system, the new separation of power

\begin{abstract}
Abstrak
Kedudukan KPK Perspektif Teori The New Separation of Powers, pada faktanya dalam sistem ketatanegaraan, menunjukkan bahwa Komisi Pemberantasan Korupsi sebagai independen organ dan tidak lagi dapat didudukkan sebagai lembaga eksekutif, serta tidak relevan lagi menggolongkan suatu lembaga negara pada 3 (tiga) cabang kekuasaan an sich, sebagaimana teori trias politica. Pada fakatnya diatas bahwa kelahiran komisi independen dapat menjalankan kekuasaan dan kewenangan lembaga sebelumnya pada rumpun eksekutif dan dialihkan menjadi lembaga independen. Bahkan tugas dan kewenangan komisi independen dapat saja bersifat quasi yudikatif dan quasi legislative. Jadi, tidak tepat lagi argumentasi yang mendudukkan Komisi Anti Korupsi sebagai eksekutif berdasarkan logika eksekutif dengan melihat sisi tugas dan fungsi yudisialnya.
\end{abstract}

Kata Kunci: KPK, Sistem Ketatanegaraan, dan the new separation of power 


\section{PENDAHULUAN}

erakan politik dan hukum yang klimaks dan ending-nya kelahiran anak Tkandung gerakan hukum dan politik yang bernama reformasi telah menghasilkan produk amandemen konstitusi negara Indonesia pada saat itu yakni amandemen ke empat Undang-Undang Dasar Negara Republik Indonesia Tahun 1945 pada tahun 2002. Filosofi gerakan amandemen tersebut bukan saja sebagai gerakan yang berimplikasi pada gerakan politik an sich. Akan tetapi, juga berimplikasi lahirnya lembaga baru dari rahim refomasi hukum in casu menurut Jimly Ashiddiqie sebagai lembaga negara yang independen mencerminkan adanya kebutuhan untuk mendekonsentrasikan kekuasaan dari tangan birokrasi atau organ-organ konvensional pemerintahan, tempat kekuasaan selama masa-masa sebelumnya terkonsentrasi. Hal ini terjadi sebagai akibat dari tuntutan perkembangan pengelolaan kekuasaan negara yang semakin kompleks dan rumit, sementara organisasi kekuasaan yang birokratis, sentralistis, dan terkonsentrasi tidak dapat diandalkan menyelesaikan kompleksitas tersebut. Oleh karenanya, muncul gelombang deregulasi, debirokratisasi, privatisasi, desentralisasi, dan dekonsentrasi, yang pada gilirannya melihat komisi negara independen sebagai jawaban dari kompleksitas ketatanegaraan modern tersebut.

A fortiriori, menurut Bruce Ackerman secara tegas mengatakan, kelahiran komisi negara independen sebagai bentuk penolakan terhadap model pemisahan Amerika Serikat. ${ }^{1}$ Argumentasi Ackerman tersebut seakan menegaskan logika latar belakang kelahiran komisi negara independen adalah konsekuensi dari transisi menuju demokrasi yang terjadi dibeberapa belahan dunia. Kelahiran komisi-komisi negara ini, baik yang bersifat independen maupun yang sebatas lembaga eksekutif, sekali lagi adalah bentuk ketidakmampuan gagasan trias politica dalam menghentikan rezim otoriter yang sempat muncul, ${ }^{2}$ bahkan dalam perkembangan ketatanegaraan melahirkan tirani dan otoritarianisme model yang baru in casu, perilaku korupsi disuatu negara.

Argumentasi tersebut, tirani dan otoritarianisme perilaku korupsi disuatu negara seakan menegaskan bahwa lahirnya lembaga independen tidak terlepas dari untuk memperbaiki kinerja lembaga sebelumnya yang gagal melawan tirani dan otoritarianisme in casu, kegagalan lembaga kejaksaan dan kepolisian yang menjalankan tugas dan fungsi pemberantasan tindak pidana korupsi. Namun, dalam kinerjanya tidak mendapat hasil yang memuaskan atau berada dalam kebobrokan kinerja. Maka dari itu lahirlah lembaga baru yang pembentukannya

${ }^{1}$ Vide, Bruce Ackerman dalam Denny Indrayana, Jangan Bunuh KPK (Malang: Intrans Publishing, ${ }^{2}$ Denny Indrayana, Jangan Bunuh KPK (Malang: Intrans Publishing, 2016), h. 52. 
berdasarkan Undang-Undang Nomor 30 Tahun 2002 Tentang Komisi Pemberantasan Tindak Pidana Korupsi yang akan meneruskan kinerja lembaga sebelumnya untuk lebih efisien dan efektif dalam menjawab kebobrokan kinerja pemberantasan tindak pidana korupsi. KPK dalam Pasal 3 UU No 30 Tahun 2002 jelas didudukkan dalam lembaga yang bersifat independen, begitu pula dalam empat putusan Mahkamah Konstitusi yakni 012-016-019/PUU-IV/2006. 19/PUUV/2007. 37-39/PUU-VIII/2010. 5/PUU-IX/2011 yang mendudukkan juga KPK sebagai lembaga negara independen.

Kehadiran lembaga anti korupsi di Indonesia tidak berjalan mulus, melawan konspirasi jahat antara koruptor, politikus dan penyelenggara negara. Menurut catatan Indonesia Corruption Watch (ICW) bahwa berbagai bentuk pelemahan dan serangan balik terhadap KPK dilakukan. Beberapa diantaranya adalah (i) adanya wacana pembubaran KPK (ii) Revisi Undang-Undang KPK, (iii) Judicial Review (Uji Materi) UU KPK ke Mahkamah Konstitusi, (iv) kriminalisasi dan rekayasa hukum terhadap pimpinan KPK, (v) Pengepungan kantor KPK, (vi) Penyerobotan kasus yng ditangani KPK, ( vii) Memblokade anggaran pembangunan gedung KPK, (viii) dan intervensi langsung dalam forum rapat kerja DPR dan KPK. ${ }^{3}$

Lagipula, memahami KPK sebagai lembaga ad hoc sehingga dibatasi keberadaannya 12 tahun, tidak memiliki pijakan hukum yang kuat. Singapura sebagai negara dengan tingkat indeks persepsi korupsi tertinggi di Asia saja masih memiliki badan antikorupsi, Corrupt Practices Investigation Bureau (CPIB) yang dibentuk sejak 1952. Atau lembaga anti korupsi Hongkong, sebagaimana Singapura, juga memiliki ICAC (Independen Commission Against Corruption), ICAC yang berdiri sejak 1974. Apakah Singapura tidak memiliki Kepolisian dan Kejaksaan? Punya, tapi pemerintah Singapura dan Hongkong sadar bahwa penanganan korupsi harus dilakukan oleh sebuah lembaga independen yang tidak berafiliasi dengan lembaga lain.

Pada realitasnya, meskipun adanya putusan Mahkamah Konstitusi a quo, secara vis a vis dengan kedudukan KPK pada putusan Mahkamah Konstitusi lainnya in casu, Putusan No. 36/PUU-XV/2017 dan Putusan No. 40/PUU$\mathrm{XV} / 2017^{4}$, justru menempatkan lembaga anti rasuah tersebut, justru pada rumpun eksekutif dan dapat dijadikan objek hak angket oleh DPR. Padahal dalam reformasi konstitusi berbagai negara juga mulai diadopsi pengaturan mengenai

\footnotetext{
${ }^{3}$ Febridiansyah, Panduan Bantuan Hukum di Indonesia, (Jakarta, Yayasan Obor Indonesia, 2014), h. 443

${ }^{4}$ Vide, misalnya pada pertimbangan hukum Mahkamah Konstitusi pada ratio decidendi, Nomor 3.20 pada Putusan No. 36/PUU-XV/2017
} 
lembaga negara independen di dalam konstitusi baru. ${ }^{5}$ Penelitian John C. Ackerman, yang juga terdapat 81 negara yang mencantumkan independent agencies di dalam konstitusinya. Dari 81 negara tersebut, tidak kurang didapat 248 lembaga negara independen yang langsung disebutkan di dalam konstitusi di empat benua; Afrika, Eropa, Amerika, dan Asia. ${ }^{6}$

Dari eskplikasi uraian antara cita dan fakta a quo, dengan demikian berdasarkan pada gap tersebut, penulis menganggap urgen dan urge (mendesak) untuk melakukan penelitian dan kajian lebih lanjut terkait tentang kedudukan dan posisi KPK pasca putusan Mahkamah Konstitusi yang mendudukkan KPK sebagai lembaga eksekutif secara kelembagaan dan sekaligus dapat dijadikan hak angket oleh DPR. Berdasarkan dari gap a quo, penulis merumuskan masalah sebagai berikut : 1) Bagaimana kedudukan KPK Perspektif Teori The New Separation of Powers; 2) Bagaimana Konstitusionalitas Putusan Mahkamah Konstitusi Perspektif Teori the New Separation of Power.

\section{PEMBAHASAN}

\section{A. Kedudukan KPK Perspektif Teori The New Separation of Powers}

Dalam konteks abad ke 20 sebagai konsekuensi lahirnya Negara kesejahteraan sebagaimana menurut Ian Gough, "the twentieth century, and in particular the period since the Second World War, can fairly be described as the era of Welfare State". 7 (sejak abad ke 20, khususnya pada periode perang dunia ke II (dua), dapat dikatakan sebagai era negara kesejahteraan. Pada abad Era welfare state tersebut, ditandai dengan kebutuhan dan intervensi negara dibidang kehidupan rakyat dan untuk menghadapi perkembangan dan kompleksitas praktik ketatanegaraan, hal tersebut sebagai konsekuensi gagasan welfare state abad ke 20, yang mengidealkan kehadiran lembaga baru tidak lain hanya untuk kepentingan melayani kebutuhan rakyat yang belum tertangani era sebelumnya.

Logika ketatanegaraan yang demikian, inherent dengan kelahiran dan bermunculnya lembaga negara yang tidak dikenal pada era sebelumnya. Lembaga negara yang dimaksud adalah lembaga negara independen. Menurut Jimly, bahwa lembaga negara tersebut lahir di negara-negara demokrasi yang telah mapan, seperti di Amerika Serikat dan Perancis, pada tiga dasawarsa terakhir abad ke-20, juga banyak bertumbuhan lembaga-lembaga negara baru. Lembaga-lembaga baru tersebut biasa disebut sebagai state auxiliary organs, atau auxiliary institutions

\footnotetext{
${ }^{5}$ Denny Indrayana, Jangan bunuh KPK (Malang: Intrans Publishing, 2016), h. 53

${ }^{6}$ Zainal Arifin Mochtar, halaman 26. Lihat pula pada Denny Indrayana, Jangan bunuh KPK (Malang: Intrans Publishing, 2016), h. 53

${ }^{7}$ Dalam Jimly Ashiddiqie, Perkembangan dan Konsolidasi Lembaga Negara Pasca Reformasi (Jakarta: Sekretariat Jenderal dan Kepaniteraan Mahkamah Konstitusi RI, 2006), h. 2
} 
sebagai lembaga negara yang bersifat penunjang. Di antara lembaga-lembaga itu, kadang-kadang ada juga yang disebut sebagai self regulatory agencies, independent supervisory bodies, atau lembaga-lembaga yang menjalankan fungsi campuran (mix function) antara fungsi-fungsi regulatif, administratif, dan fungsi penghukuman yang biasanya dipisahkan tetapi justru dilakukan secara bersamaan oleh lembaga-lembaga baru tersebut. ${ }^{8}$ Bahkan sebagai konsekuensi lahirnya lembaga negara independen tersebut, menurut Jimly, bahwa salah satu akibatnya, fungsi-fungsi kekuasaan yang biasanya melekat dalam fungsi-fungsi lembagalembaga eksekutif, legislatif, dan bahkan yudikatif dialihkan menjadi fungsi organ tersendiri yang bersifat independen. Karena itu, kadang-kadang lembaga-lembaga baru tersebut menjalankan fungsi-fungsi yang bersifat campuran, dan masingmasing bersifat independen (independent bodies). ${ }^{9}$

Sinyalemen Jimly Ashiddiqie tersebut, nampaknya mengindikasikan dan menguatkan argumentasi logis kelahiran Komisi Pemberantasan Korupsi (KPK), yang justru menjalankan fungsi-fungsi yang melekat pada lembaga cabang eksekutif. Hal ini, sesuai latar belakang dan alasan mengapa dibutuhkan suatu lembaga anti korupsi, yakni sesuai dengan ratio legis Undang-Undang No. 30 Tahun 2002 Tentang Komisi Pemberantasan Korupsi, sebagai berikut :

Bahwa lembaga pemerintah yang menangani perkara tindak pidana korupsi belum berfungsi secara efektif dan efisien dalam memberantas tindak pidana korupsi;

Peralihan fungsi eksekutif menjadi lembaga tersendiri yang bersifat independen sesuai dengan pertimbangan pembentukan lembaga Komisi Pemberantasan Korupsi yang telah dialihkan menjadi fungsi organ tersendiri yang bersifat independen, sebagaimana ratio legis Undang-Undang No. 30 Tahun 2002 Tentang Komisi Pemberantasan Korupsi, sebagai berikut :

"Bahwa sesuai dengan ketentuan Pasal 43 Undang-Undang Nomor 31 Tahun 1999 tentang Pemberantasan Tindak Pidana Korupsi sebagaimana telah diubah dengan Undang-Undang Nomor 20 Tahun 2001 tentang Perubahan atas Undang-Undang Nomor 31 Tahun 1999 tentang Pemberantasan Tindak Pidana Korupsi, perlu dibentuk Komisi Pemberantasan Tindak Pidana Korupsi yang independen dengan tugas dan wewenang melakukan pemberantasan tindak pidana korupsi."

Ratio legis pembentukan Komisi Pemberantasan Korupsi a quo, menunjukkan bahwa peralihan tugas-tugas dan fungsi-fungsi lembaga eksekutif menjadi lembaga independen sesuai indikator lembaga negara independen sebagaimana yang dikemukakan oleh William F. Fox Jr. yang berargumen bahwa

${ }^{8}$ Jimly Ashiddiqie, Perkembangan dan Konsolidasi Lembaga Negara Pasca Reformas, h. 8

${ }^{9}$ Jimly Ashiddiqie, Perkembangan dan Konsolidasi Lembaga Negara Pasca reformasi, h. 23 
suatu komisi negara adalah independen bila dinyatakan secara tegas oleh kongres dalam undang-undang komisi yang bersangkutan. ${ }^{10}$ Argumentasi fox, juga relevan dengan pendapat Lisa Schultz Bressman dan Robert B. Thompson, bahwa untuk menentukan apakah lembaga negara tersebut sebagai Independent Agencies ataukah sebagai Executive-Branch Agencies, tidak ada cara lain hanya melalaui parlemen sebagai pembentuk undang-undang untuk mendesain lembaga negara pada lapis ke dua (pembentukannya berdasarkan Undan-Undang), sebagaimana pendapat Lisa Schultz Bressman dan Robert B. Thompson dengan menyatakan When Congress seeks to delegate a regulatory function, a key design choice is whether to grant that function to an independent agency or an executivebranch agency ${ }^{11}$. Di Amerika misalnya, independent agencies, yang menjalankan kewenangan lembaga eksekutif dan dialihkan menjadi independen agencies adalah the Commodity Futures Trading Commission ("CFTC") berdasarkan Commodity Exchange Act ${ }^{12}$, untuk menguatkan argumentasi dan relalitas independent agencies di Amerika tersebut, juga memiliki relasi dengan pendapat Dina Misiroglu yang pada pokoknya mengatakan, begitu juga dengan komisi negara independen di Amerika Serikat adalah lembaga negara federal yang tidak termasuk cabang kekuasaan eksekutif, dan karenanya tidak berada di bawah kontrol presiden. ${ }^{13}$

Argumentasi Fox Jr diatas, menunjukkan bahwa dalam sistem ketatanegaraan modern, tidak lagi dapat mempertahankan teori separation of power sebagaimana yang dielaborasi oleh Montesquieu. Bahkan dalam perkembangan ketatanegaraan, realitas demikian telah ditinggalkan dalam praktek ketatanegaraan modern. Misalnya, di negara Amerika Serikat pada faktanya menurut Bruce Ackerman ${ }^{14}$ sebagai avant garde (perintis) teori the new separation of power-nya, yang pada pokoknya di sistem ketatanegaraan Amerika telah bergeser dari trias politica yang ditandai kelahiran lembaga independen. Lebih detail pendapat Bruce Ackerman yang pada pokoknya sebagai berikut :

\footnotetext{
${ }^{10}$ William F. Fox Jr, Understanding Administrative Law, (Matthew Bender \& Company, Inc., a member of the LexisNexis Group, 2000), h. 56

${ }^{11}$ Lisa Schultz Bressman \& Robert B. Thompson, The Future of Agency Independenc, Journal Vanderbilt Law Review, Volume 3 Number 3, 2010, h. 607.

${ }^{12}$ Lisa Schultz Bressman \& Robert B. Thompson, The Future of Agency Independenc, h. 607.

${ }^{13}$ Dikutip dalam Denny Indrayana, Jangan Bunuh KPK: Kajian Hukum Tata Negara Penguatan Komisi Pemberantasan Korupsi (Malang:Intrans Publisihing, 2016), h. 47. Vide as well, Jennifer L. Selin yang menyatakan lembaga independen yang bebas dari control presiden dengan menyatakan bahwa president cannot remove members except for neglect of duty or malfeasance in office. Jennifer L. Selin, What Makes an Agency Independent?, Working Paper, Research Concentration: Executive Politics and Regulatory Policymaking, h. 5.

${ }^{14}$ Bruce Ackerman, The New Separation of Powers, Journal Harvard Law Review vol. 113, Januari Tahun 2000, h. 724
} 
The American system contains (at least) five branches: House, Senate, President, Court, and independent agencies such as the Federal Reserve Board. Complexity is compounded by the bewildering institutional dynamics of the American federal system. The crucial question is not complexity, but whether we Americans are separating power for the right reasons.

Realitas yang diaksentuasikan oleh Bruce Ackerman tersebut, juga memiliki relasi dengan pendapat Cindy $\mathrm{Skach}^{15}$, yang menjelaskan bahwa tidak hanya pada sistem ketatanegaraan Amerika serikat telah mengubur masa depan teori trias politica. Akan tetapi, juga di negara Eropa Timur in casu, Rusia dan bahkan tempat kelahiran teori trias politica-pun (France) tidak lagi mempertahankan tiga cabang kekuasaan secara terpisah. Akan tetapi, telah terdapat 6 cabang kekuasaan sebagaimana pendapat Skach, yakni : DPR, senat, President as head of state, Prime Minister as head of executive, Yudikatif, dan Independent Agencies.

Selain fakta yang telah diteliti oleh Ackerman dan Skach a quo, dengan fakta tidak relevan lagi dipertahankan gagasan trias politica. Dari hasil penelusuran penulis, bahwa kelahiran lembaga independen misalnya komisi anti korupsi berdasarkan konstitusi Thailand, mendudukkan lembaga Komisi Anti Korupsi-nya sebagai lembaga independence agencies, selain lembaga independen lainnya. yakni Election Commission, Ombudsmen, State Audit Commission, Prosecution Organization, National Human Rights Commission, National Economic and Social Advisory Council. Hal tersebut sebagaimana diatur berdasarkan Chapter XI: Organizations Under the Constitution, pada Part 1 Tentang Independent Organizations Under the Constitution dan pada Part 2 Tentang Other Organizations Under the Constitution. ${ }^{16}$ Untuk menguatkan argumentasi kedudukan lembaga komisi anti korupsi sebagai lembaga independen dan bebas dari control kepala eksekutif (presiden/perdana menteri) di negara Thailand, dapat dilihat pada Section 20 ayat (6), berdasarkan Amandemen Konstitusi Tahun 2014 di Thailand ${ }^{17}$, yang pada pokoknya sebagai berikut :

The Prime Minister and Minister shall have the qualifications and not being under the prohibitions as follows: not being a judge of the Constitutional Court, a judge of any Court, a State Attorney, a commissioner of the Election Commission, an Ombudsman, a commissioner of the National Counter Corruption Commission, a

15 Cindy Skach, The "newest" Separation of Powers: Emipresidentialism, Journal I-CON, Volume 5, Number 1, 2007, h. 117-119,

16 Thailand's Constitution of 2014, constituteproject.org. Diakses pada tanggal 22 Februari 2018.

17 Thailand's Constitution of 2014, constituteproject.org. Diakses pada tanggal 22 Februari 2018. 
commissioner of the State Audit Commission, the Auditor-General or a member of the Human Rights Commission

Berdasarkan konstitusi Thailand a quo, bahwa kedudukan komisi anti korupsi-nya sebagai independent agencies yang sama kedudukannya dengan organ konstitusi yang independen lainnya. Selain negara Thailand yang mendudukkan Komisi Anti Korupsi-nya sebagai Independence agencies dan sebagai constitutional organ, di negara Fhilipina berdasarkan The 1987 Constitution of the Republic of the Philippines ${ }^{18}$, pada Section 5, sebagai berikut : There is hereby created the independent Office of the Ombudsman, composed of the Ombudsman to be known as Tanodbayan, one overall Deputy and at least one Deputy each for Luzon, Visayas, and Mindanao. A separate Deputy for the military establishment may likewise be appointed.

Sedangkan terkait kewenangan, fungsi dan tugas Office of the Ombudsman sebagai independent agencies, yakni berdasarkan pada Section 13, sebagai berikut : The Office of the Ombudsman shall have the following powers, functions, and duties: (1) Investigate on its own, or on complaint by any person, any act or omission of any public official, employee, office or agency, when such act or omission appears to be illegal, unjust, improper, or inefficient; and (3) Direct the officer concerned to take appropriate action against a public official or employee at fault, and recommend his removal, suspension, demotion, fine, censure, or prosecution, and ensure compliance therewith.

Berdasarkan tugas dan fungsi serta kewenangan komisi anti korupsi di Fhilipina sebagaimana eksplikasi a quo, yang pada pokoknya tidak saja sebagai penyelidik dan penyidikan. Akan tetapi juga melakukan prosecution (penuntutan) perkara korupsi. A fortiori, untuk menguatkan argumentasi penulis, berdasarkan konstitusi Zimbabwe ${ }^{19}$ bahwa Komisi Anti Korupsi Zimbabwe yang bernama The Zimbabwe Anti-Corruption Commission (ZACC) is an independent commission created to combat corruption and crime. It is established in terms of Chapter 13, Part 1 of the Zimbabwe's Constitution of 2013. Fungsi dan tugas The Zimbabwe Anti-Corruption Commission (ZACC) justru identik dengan tugas dan fungsi yudisial jaksa dan kepolisian di Indonesia berdasarkan pada article $255^{20}$, the Zimbabwe's Constitution of 2013.

\footnotetext{
${ }^{18}$ The 1987 Constitution of the Republic of the Philippines, http://www.dotr.gov.ph/images/front/GAD/issuances/1987constitution.pdf. Diaksesk pada tanggal 22 Februari 2018.

${ }^{19}$ Zimbabwe's Constitution of 2013 (pdf), constituteproject.org. Vide as well (lihat juga)l, Transparency International Zimbabwe, http://tizim.org/wp-content/uploads/2016/05/faq6.pdf. Diaksesk pada tanggal 22 Februari 2018.

${ }^{20}$ Fungsi tugas Komisi Anti Korupsi di Zimbabwe sebagai berikut : a. to investigate and expose cases of corruption in the public and private sectors; $\boldsymbol{b}$. to combat corruption, theft, misappropriation, abuse
} 
Selain kedudukan Komisi Anti Korupsi sebagai independent agencies berdasarkan konstitusi, komisi anti korupsi yang independen diberbagai negara juga kedudukannya sebagai lembaga negara dibentuk berdasarkan undang-undang atas amanat konstitusi. Misalnya, pada Egypt's Constitution of 2014 pada Article 218 section eleven (sebelas) dalam subsection two tentang Independent bodiest and regulatory Agencies. Hal tersebut berdasarkan, yang mengatur sebagai berikut : ${ }^{21}$

The state is committed to fighting corruption, and the competent control bodies and organizations are identified by law... (Negara berkomitmen untuk memerangi korupsi dan lembaga kontrol yang berkompoten dibentuk berdasarkan undang-undang.

Selain di Mesir yang mendudukkan lembaga anti korupsi berdasarkan Undang-Undang, juga sebagaimana di Afrika Selatan merupakan lembaga yang berdasarkan Undang-Undang in casu, berdasarkan pada Anti Corruption Act pada Chapter 1 pada angka 7. Pada Chapter tersebut kedudukan komisi anti korupsi secara expressive verbis. Lebih detailnya sebgai berikut : Independence of the Anti-Corruption Unit The Anti Corruption Unit: (1) Is independent and subject only to the Constitution and the law;; (2) Must be impartial and perform its functions without fear, favour or prejudice; and (3) Required to submit reports four times a year to Parliament.

Berdasarkan dari eksplikasi diatas, menunjukkan bahwa, argumentasi dan fakta sistem ketatanegaraan, menunjukkan bahwa Komisi Pemberantasan Korupsi sebagai independen organ dan tidak lagi dapat didudukkan sebagai lembaga eksekutif, serta tidak relevan lagi menggolongkan suatu lembaga negara pada 3 (tiga) cabang kekuasaan an sich, sebagaimana teori trias politica. Argumentasi penulis, pada faktanya diatas bahwa kelahiran komisi independen dapat menjalankan kekuasaan dan kewenangan lembaga sebelummnya pada rumpun eksekutif dan dialihkan menjadi lembaga independen. Bahkan tugas dan kewenangan komisi independen dapat saja bersifat quasi yudikatif dan quasi legislative. Jadi, tidak tepat lagi argumentasi yang mendudukkan komisi anti korupsi sebagai eksekutif berdasarkan logika eksekutif dengan melihat sisi tugas

of power and other improper conduct in the public and private sectors; $c$. to promote honesty, financial discipline and transparency in the public and private sectors; $\boldsymbol{d}$. to receive and consider complaints from the public and to take such action in regard to the complaints as it considers appropriate; $\boldsymbol{e}$. to direct the Commissioner-General of Police to investigate cases of suspected corruption and to report to the Commission on the results of any such investigation; $f$. to refer matters to the National Prosecuting Authority for prosecution; $g$. to require assistance from members of the Police Service and other investigative agencies of the State; and $\boldsymbol{h}$. to make recommendations to the Government and other persons on measures to enhance integrity and accountability and prevent improper conduct in the public and private sectors.

${ }^{21}$ Egypt's Constitution of 2014 https://www.constituteproject.org/constitution/Egypt_2014.pdf. Diakses pada tanggal 25 Februari 2018, h.54. 
dan fungsi yudisialnya. Misalnya, konstitusi Zimbabwe pada article 255 yang dimana tugas dan fungsinya sama dengan kejaksaan dan kepolisian, yakni sebagai penyelidik, penyidikan, dan penuntutan perkara korupsi, begitu juga di Fhilipina, serta Thailand.

\section{B. Kritik Logika Putusan Mahkamah Konstitusi Perspektif Teori the New Separation of Power}

Mahkamah konstitusi dalam mengadili perkara judicial review, menurut Adnan Jamal bahwa hakim konstitusi dalam menjalankan kewenangannya terutama dalam hal judicial review selalu berkutat dalam domain penafsiran teks norma hukum. Walaupun tidak ada ketentuan konstitusional, hakim konstitusi secara logis adalah penafsir konstitusi dalam menjalankan kewenangan konstitusionalnya. Dalam konteks inilah, hakim konstitusi berpotensi mengidap kerakusan nafsu yudisial - meminjam istilah Lois Blom Cooper QS. Selain itu, hakim konstitusi dalam memeriksa dan memutus perkara, misalnya judicial review senantiasa berhadapan secara vis a vis dengan sejumlah antinomi antara lain teks dan konteks, mayoritas dan minoritas, dan antara ide atau pretensi subjektif dan obyektif. Sejumlah antinomi tersebut diperhadapkan dalam suatu alam sorgawi kemerdekaan mereka. Tidak ada demarkasi dan petunjuk normatif secara eksplisit tentang bagaimana hakim konstitusi menafsir konstitusi. Sekali lagi, hakim konstitusi berpotensi besar melakukan semacam anarkisme konstitusi. $^{22}$

A fortiori, anarkisme konstitusi tersebut sebagaimana pada putusan mahkamah konstitusi merupakan perdebatan wacana ketatanegaraan yang tidak saja perdebatan terkait dengan perluasan objek hak angket. Akan tetapi juga terkait dengan konstitusionalitas hak angket terhadap kedudukan lembaga KPK yang independen. A fortiori, putusan Mahkamah Konstitusi Nomor 36/PUUXV/2017 dan putusan Nomor 40/PUU-XV/2017, telah mendudukkan Komisi Pemberantasan Korupsi sebagai lembaga negara rumpun eksekutif. Hal tersebut sebagaimana pada ratio decidendi putusan Mahkamah Konstitusi Nomor 40/PUU $\mathrm{XV} / 2017^{23}$, sebagai berikut : Bahwa oleh karena KPK merupakan lembaga yang berada di ranah eksekutif yang melaksanakan tugas penyelidikan, penyidikan, penuntutan dalam perkara tindak pidana korupsi yang sejatinya merupakan kewenangan Kepolisian dan/atau Kejaksaan, bahkan dengan mengingat fungsi KPK sebagai lembaga khusus untuk mendorong agar pemberantasan korupsi

\footnotetext{
${ }^{22}$ Adnan Jamal, Hakim Konstitusi: antara Penegakan Supremasi Konstitusi dan Anarkisme Konstitusi, Jurnal Ilmu Hukum AMANNA GAPPA, Vol. 19 Nomor 2, Juni 2011, h. 129.

${ }^{23}$ Vide, h. 181
} 
dapat berjalan secara efektif, efisien, dan optimal, maka dapat disimpulkan dengan sendirinya bahwa KPK dapat menjadi objek dari hak angket DPR dalam fungsi pengawasannya. Dengan demikian, dalam melaksanakan fungsi pengawasannya, DPR dapat menggunakan hak konstitusionalnya termasuk hak angket terhadap KPK hanya terbatas pada hal-hal yang berkaitan dengan pelaksanaan tugas dan kewenangan KPK selain pelaksanaan tugas dan kewenangan yang berkaitan dengan tugas dan kewenangan yudisialnya (penyelidikan, penyidikan, dan penuntutan).

Selain pada putusan Mahkamah Konstitusi Nomor 40/PUU-XV/2017 di atas, yang mendudukkan KPK sebagai rumpun eksekutive organ, putusan Mahkamah Konstitusi Nomor 36/PUU-XV/2017 juga mendudukkan KPK sebagai lembaga eksekutif. Hal tersebut sebagaimana pada ratio legis-nya pada nomor [3.20] sebagai berikut :

"Menimbang bahwa oleh karena KPK merupakan lembaga yang berada di ranah eksekutif yang melaksanakan tugas penyelidikan, penyidikan, dan penuntutan dalam perkara tindak pidana korupsi yang sejatinya merupakan kewenangan Kepolisian dan/atau Kejaksaan, bahkan dengan mengingat fungsi KPK sebagai lembaga khusus untuk mendorong agar pemberantasan korupsi dapat berjalan secara efektif, efisien, dan optimal, maka dapat disimpulkan dengan sendirinya bahwa KPK dapat menjadi objek dari hak angket DPR dalam fungsi pengawasannya. Dengan demikian, dalam melaksanakan fungsi pengawasannya, DPR dapat menggunakan hak-hak konstitusionalnya termasuk hak angket terhadap KPK hanya terbatas pada hal-hal yang berkaitan dengan pelaksanaan tugas dan kewenangan KPK selain pelaksanaan tugas dan kewenangan yang berkaitan dengan tugas dan kewenangan yudisialnya (penyelidikan, penyidikan, dan penuntutan)." 24

Berdasarkan dari argumentasi hukum oleh hakim konstitusi sebagaimana pada ratio legis-nya a quo, sebagaimana pada putusan Mahkamah Konstitusi Nomor 40/PUU-XV/2017 dan Nomor 36/PUU-XV/2017, terdapat keanehan dalam membangun konstruksi logika hukum. Misalnya, hakim konstitusi dengan membangun argumentasi KPK merupakan lembaga yang berada di ranah eksekutif yang melaksanakan tugas penyelidikan, penyidikan, dan penuntutan dalam perkara tindak pidana korupsi yang sejatinya merupakan kewenangan Kepolisian dan/atau Kejaksaan. Pada saat yang sama, justru dasar argumentasi tersebut (yang melaksanakan tugas penyelidikan, penyidikan, dan penuntutan dalam perkara tindak pidana korupsi yang sejatinya merupakan kewenangan Kepolisian dan/atau Kejaksaan), sebagai dasar menentukan karakter lembaga

${ }^{24}$ Vide, Putusan Mahkamah Konstitusi Nomor 36/PUU-XV/2017, h. 109-110. 
eksekutif justru tidak dapat dilakukan kewenangan hak angket oleh DPR. Berdasarkan dengan logika tersebut, hakim konstitusi nampaknya melakukan kekeliruan dalam membangun konstruksi argumentasi rasional dan konstitusional. A fortiori, putusan Mahkamah Konstitusi tersebut juga tidak sesuai dengan praktik ketatanegaraan modern yang dimana cabang kekuasaan tidak lagi berdasarkan 3 (tiga) sebagaimana yang didalilkan oleh Montesquieu. Kritik doktrin Montesqueu juga ekuivalent dengan pendapat Jimly Ashiddiqie, yang menyatakan bahwa : ${ }^{25}$

"Konsepsi trias politica yang diidealkan oleh Montesquieu ini jelas tidak relevan lagi dewasa ini, mengingat tidak relevan lagi dewasa ini, mengingat tidak mungkin lagi mempertahankan bahwa ketiga organisasi tersebut hanya berurusan secara eksklusif dengan salah satu dari ketiga fungsi kekuasaan tersebut. Kenyataan dewasa menunjukkan bahwa hubungan antar cabang kekuasaan itu tidak mungkin tidak saling bersentuhan, dan bahkan ketiganya bersifat sederajat dan saling mengendalikan satu sama lain sesuai dengan prinsip checks and balances."

Terlepas dengan tidak relevannya lagi doktrin trias politica dalam menghadapi tantangan yang kompleks dan kebutuhan ketatanegaraan modern. Dengan demikian, putusan mahkamah konstitusi tersebut sebagaimana dalam pertimbangan hukumnya menunjukkan bahwa hakim konstitusi tidak melakukan tafsiran sesuai dengan original intent dan nyaris melakukan ramalan ketatanegaraan. Ramalan konstitusional oleh hakim konstitusi pada ratio decidendi berikutnya sangat aneh dalam menafsirkan kedudukan lembaga negara. Kekeliruan tersebut sebagaimana pada ratio legis-nya yang pada pokoknya mendalilkan sebagai berikut $:^{26}$

"Dengan kata lain, lembaga-lembaga negara penunjang tersebut dibentuk dengan tetap berdasar pada fungsi lembaga negara utama yang menjalankan tiga fungsi: legislatif, eksekutif, dan yudikatif. Artinya, baik pada pada ranah eksekutif, legislatif, maupun yudikatif, dimungkinkan muncul lembaga penunjang untuk mendukung kompleksitas fungsi lembaga utama. Tujuan pembentukannya jelas, yakni dalam rangka efektivitas pelaksanaan kekuasaan yang menjadi tanggung jawab lembaga-lembaga utama tersebut."

Kekeliruan pertimbangan hukum hakim konstitusi tersebut, yakni tidak mengakui kedudukan lembaga independen dan memaksa lembaga independen harus dimasukkan dan dikategorikan pada 3 (tiga) cabang kekuasaan sebagaimana

${ }^{25}$ Jimly Ashiddiqie, Perkembangan dan Konsolidasi Lembaga Negara Pasca Reformasi (Jakarta: Sekretariat Jenderal dan Kepaniteraan Mahkamah Konstitusi RI, 2006), h. 35.

${ }^{26}$ Vide, pertimbangan hukum pada putusan Mahkamah Konstitusi No. 36/PUU-XV/2017. h. 108. 
doktrin trias politica. Jika memaksa dimasukkan dan dikategorikan pada 3 (tiga) cabang kekuasaan a quo, lembaga negara penunjang yang didalilkan hakim konstitusi dalam ratio decidendi-nya pada No. $(3.18)^{27}$ seperti Komisi Penyiaran Indonesia (KPI), Komisi Yudisial (KY), Komisi Pemilihan Umum (KPU), Komisi Nasional Hak Asasi Manusia (Komnas HAM), dimasukkan dan dikategorikan sebagai eksekutif, atau legislatif, dan yudikatif? Jika pertimbangan hukum sebagaimana diatas yang harus diikuti, maka akan terjadi konflik ketatanegaraan kedepannya dan lembaga negara independen tersebut nyaris juga kedepannya dilakukan hak angket. Padahal lembaga negara tersebut meskipun bersifat menunjang, tetapi tidak rasional jika harus dipaksakan masuk dan dikategorikan sebagai salah satu dari tiga cabang kekuasaan seperti doktrin trias politica. Lagi pula, dalam praktik ketatanegaraan dan berdasarkan konstitusi di dunia ini tidak satupun negara menempatkan electoral commission dan Komnas HAM, serta Komisi Penyiaran Indonesia selain independent agencies.

Logika argumentasi tersebut, menunjukkan bahwa komisi negara independen berbeda dengan komisi negara biasa (state commissions). Menurut Michael R. Asimow, komisi negara biasa hanyalah bagian dari eksekutif dan tidak mempunyai peran yang terlalu penting. ${ }^{28}$ Misalnya, Komisi Polisi Nasional (kompolnas) dan Komisi Kejaksaan. Argumentasinya, pembentukan komisi tersebut dibentuk berdasarkan pemberian delegasi kepada Kejaksaan dan kepolisian untuk membentuk komisi tersebut. Selain argumentasi tersebut, seharusnya hakim konstitusi dalam mendudukkan KPK sebagai rumpun eksekutif, memerhatikan putusan Mahkamah Konstitusi No: 012-016-019/PUU-IV/2006, 19/PUU-V/2007, 37-39/PUU-VIII/2010. 5/PUU-IX/2011. Argumentasinya, putusan terdahulu secara mutatis mutandis berlaku pada saat DPR melakukan hak angket terhadap KPK. Selain itu, konsekuensi putusan Mahkamah Konstitusi yang final and binding harus ditafsirkan putusan Mahkamah Konstitusi yang terbaru tidak boleh menyimpangi putusan Mahkamah Konstitusi sebelumnya ${ }^{29}$, karena tidak terdapat sarana upaya hukum manakala terdapat pertentangan tafsir. A fortiori, putusan Mahkamah Konstitusi bersifat erga omnes. Untuk memperkuat argumentasi penulis untuk melakukan kritik terhadap putusan Mahkamah

${ }^{27}$ Vide, pertimbangan hukum pada putusan Mahkamah Konstitusi No. 36/PUU-XV/2017. h. 108.

28Michael R. Asimow, Administrative Law (Foundation Press, 2014), h. 2.

${ }^{29}$ Ratio decidendi putusan Mahkamah Konstitusi No. 19/PUU-V/2007 dengan menimbang : Sedemikian luar biasa sifat tindak pidana korupsi tersebut sehingga pembentuk undang-undang pun menyadari dan mengakui bahwa institusi-institusi yang telah ada (sebelum dibentuknya Komisi Pemberantasan Tindak Pidana Korupsi) belum optimal dalam melaksanakan fungsinya untuk memberantas tindak pidana korupsi (vide Konsiderans huruf a dan Penjelasan Umum UU KPK). Oleh karena itu, pembentuk undang-undang memandang perlu membentuk suatu lembaga tersendiri, yaitu Komisi Pemberantasan Tindak Pidana Korupsi (KPK), yang diberi kewenangan besar dan tugas-tugas yang sangat luas dalam rangka mencegah dan memberantas tindak pidana korupsi. 
Konstitusi Nomor 40/PUU-XV/2017 dan Nomor 36/PUU-XV/2017 tersebut, tidak terlepas dengan analisis Lawrence Baum yang pada pokoknya bahwa tujuan dari partisan hakim tidak terlepas dengan persoalan tawar menawar proses rekruitmen seorang hakim. Preposisi Baum tersebut dengan menyatakan goals and motives into account is that it provides a useful perspective on the recruitment process for judges. ${ }^{30}$ Proses tawar menawar tersebut, lebih lanjut dijelaskan oleh Baum, pada proses rekruitmen hakim sebagai the motivational profiles of courts.

Sinyalemen pada argumentasi dari Lawrence Baum a quo, memberikan sinyal bahwa seorang hakim in casu, termasuk hakim konstitusi dalam mengadili suatu perkara, inevitably dari anasir non-hukum (politik) dalam mengadili suatu perkara. A fortiori, jika perkara tersebut in casu, judicial review terhadap undangundang yang diuji terkait dengan posisi politik partisan yang menentukan proses rekruitmen dan masa depan hakim mahkamah konstitusi. Selain itu, dari argumentasi Lawrence Baum, juga membuktikan bahwa posisi Mahkamah konstitusi memiliki posisi twe petten, yakni sebagai lembaga yudikatif di sisi lainnya sekligus sebagai institusi politik. Jadi, tidak mengherankan jika hakim konstitusi sebagai courts as victims or targets of populist politics.

Pendapat Baum tersebut, nampaknya memiliki relasi dengan pendapat Nuno Garoupa and Tom Ginsburg, yang pada pokoknya menyatakan sebagai berikut :

External incentives come from outside of the judiciary, re-flecting the views of society or public opinion in general, but also the interests of the particular relevant constituencies with power over the court.

Pandangan Nuno Garoupa dan Tom Ginsburg tersebut memberikan sinyalemen bahwa putusan hakim dalam mengadili suatu perkara tidak akan mungkin tidak terpengaruh kepentingan konstituen dan pengaruh eksternal in casu, opini publik secara umum dan juga kepentingan konstituen yang relevan dengan kekuasaan atas pengadilan. Lebih lanjut Pandangan Garoupa dan Ginsburg, konstituen yang dimaksud adalah the bar, academic com-mentators, other branches of government, as well as political parties and others, depending on the institutional environment of courts. ${ }^{31}$.

Berdasarkan dari argumentasi di atas, menunjukkan bahwa hakim konstitusi dalam putusannya No. 36/PUU-XV/2017 dan No. 40/PUU-XV/2017 justru semakin menjauh dari kewajiban konstitusional-nya sebagai the sole of the

${ }^{30}$ Lawrence Baum, Motivation and Judicial Behavior: Expanding the Scope of Inquiry (Paper for Workshop on Exploring the Judicial Mind, University of Virginia, March 30-31, 2007), h. 13.

${ }^{31}$ Nuno Garoupa and Tom Ginsburg, Judicial Audiences and Reputation: Perspectives from Comparative Law, Columbia Journal Of Transnational Law 7, (Columbia Journal of Transnational Law 451, 2009), h. 458-459. 
interpretator of constitution, karena gagal dalam menemukan original intent dan gagal menjadi sebagai the guardian's of constitution dalam menjalankan kewenangan mahkotanya yakni judicial review, karena Mahkamah Konstitusi mendudukkan Komisi Pemberantasan Korupsi sebagai "keluarga" eksekutif dengan konstruksi logika kontradiksi dalam bangunan argumentasinya sendiri dengan menggunakan dalil fungsi yudisial sebagai eksekutif dan disisi lainnya juga digunakan dalil fungsi yudisial sebagai eksekutif tidak dapat diangket oleh DPR. Selain itu, putusan mahkamah Konstitusi a quo, juga sangat kontradiksi terhadap logika konstitusional serta hakim konstitusi menunjukkan tidak up to date terhadap perkembangan ketatanegaraan modern di dunia dan perkembangan lembaga negara independence agencies di dunia, termasuk tempat kelahiran trias politica yang justru telah menjadi "almarhum". Selain itu, hakim Konstitusi dalam putusannya a quo, telah terjerat barter kepentingan politik DPR untuk kepentingannya sendiri. Padahal hakim konstitusi bukan sebagai the guardian's of political parties.

\section{PENUTUP}

Bahwa Kedudukan KPK Perspektif Teori The New Separation of Powers, argumentasi dan fakta sistem ketatanegaraan, menunjukkan bahwa Komisi Pemberantasan Korupsi sebagai independen organ dan tidak lagi dapat didudukkan sebagai lembaga eksekutif, serta tidak relevan lagi menggolongkan suatu lembaga negara pada 3 (tiga) cabang kekuasaan an sich, sebagaimana teori trias politica. Argumentasi penulis, pada fakatnya diatas bahwa kelahiran komisi independen dapat menjalankan kekuasaan dan kewenangan lembaga sebelumnya pada rumpun eksekutif dan dialihkan menjadi lembaga independen. Bahkan tugas dan kewenangan komisi independen dapat saja bersifat quasi yudikatif dan quasi legislative. Jadi, tidak tepat lagi argumentasi yang mendudukkan Komisi Anti Korupsi sebagai eksekutif berdasarkan logika eksekutif dengan melihat sisi tugas dan fungsi yudisialnya. Misalnya, konstitusi Zimbabwe pada article 255 yang dimana tugas dan fungsinya sama dengan Kejaksaan dan kepolisian, yakni sebagai penyelidik, penyidikan, dan penuntutan perkara korupsi. Begitu juga di Fhilipina, serta Thailand. Konsekuensinya, putusan Mahkamah Konstitusi No. 36/PUU-XV/2017 dan No. 40/PUU-XV/2017, dalam pertimbangan hukumnya justru semakin menjauh dari kewajiban konstitusionalnya sebagai the sole of the interpretator of constitution, karena gagal dalam menemukan original intent dan gagal menjadi sebagai the guardian's of constitution dalam menjalankan kewenangan mahkotanya yakni judicial review, karena Mahkamah Konstitusi mendudukkan Komisi Pemberantasan Korupsi sebagai "keluarga" eksekutif 
dengan konstruksi logika kontradiksi dalam bangunan argumentasinya sendiri dengan menggunakan dalil fungsi yudisial sebagai eksekutif dan disisi lainnya juga digunakan dalil fungsi yudisial sebagai eksekutif tidak dapat diangket oleh DPR. Selain itu, putusan mahkamah Konstitusi a quo, juga intensif. Misalnya dengan mengadakan penyuluhan hukum kepada nelayan secara berkala. sangat kontradiksi terhadap logika konstitusional serta hakim konstitusi menunjukkan tidak up to date terhadap perkembangan ketatanegaraan modern di dunia dan perkembangan lembaga negara independence agencies di dunia, termasuk tempat kelahiran trias politica yang justru telah menjadi "almarhum". Selain itu, hakim konstitusi dalam putusannya a quo, telah terjerat barter kepentingan politik DPR untuk kepentingannya sendiri. Padahal hakim konstitusi bukan sebagai the guardian's of political parties. 


\section{DAFTAR PUSTAKA}

\section{BUKU DAN JURNAL}

Ackerman. Bruce, 2000. The New Separation of Powers, Journal Harvard Law Review vol. 113, Januari.

Adnan Jamal, 2011, Hakim Konstitusi: antara Penegakan Supremasi Konstitusi dan Anarkisme Konstitusi, Jurnal Ilmu Hukum AMANNA GAPPA, Vol. 19 Nomor 2, Juni 2011.

Baum. Lawrence, 2007, Motivation and Judicial Behavior: Expanding the Scope of Inquiry, Paper for Workshop on Exploring the Judicial Mind, University of Virginia, March 30-31.

Denny Indrayana, 2016. Jangan Bunuh KPK: Kajian Hukum Tata Negara Penguatan Komisi Pemberantasan Korupsi, Intrans Publisihing, Malang,

F. Fox Jr. William, 2000. Understanding Administrative Law, Matthew Bender \& Company, Inc., a member of the Lexis Nexis Group.

Febridiansyah, 2014, Panduan Bantuan Hukum di Indonesia, Yayasan Obor Indonesia, Jakarta.

Jimly Ashiddiqie, 2006. Perkembangan dan Konsolidasi Lembaga Negara Pasca Reformasi, Sekretariat Jenderal dan Kepaniteraan Mahkamah Konstitusi RI, Jakarta

L. Selin. Jennifer, What Makes an Agency Independent?, Working Paper, Research Concentration: Executive Politics and Regulatory Policymaking.

Lisa Schultz Bressman \& Robert B. 2010. Thompson, The Future of Agency Independenc, Journal of Vanderbilt Law Review, Volume 3 number 3,

Nuno Garoupa and Tom Ginsburg, 2009, Judicial Audiences and Reputation: Perspectives from Comparative Law, Columbia Journal of Transnational Law 451.

R. Asimow. Michael, 2014. Administrative Law, Foundation Press.

Skach. Cindy, 2007. The "newest" Separation of Powers: Emipresidentialism, Journal I-CON, Volume 5, Number 1.

\section{KONSTITUSI DAN PUTUSAN MAHKAMAH KONSTITUSI}

Putusan Mahkamah Konstitusi No. 19/PUU-V/2007.

Putusan Mahkamah Konstitusi Nomor 36/PUU-XV/2017.

Thailand's Constitution of 2014, constituteproject.org. Diakses pada tanggal 22 Februari 2018.

The 1987 Constitution of the Republic of the Philippines, http://www.dotr.gov.ph/images/front/GAD/issuances/1987constitution.pdf . Diakses pada tanggal 22 Februari 2018.

Zimbabwe's Constitution of 2013 (pdf), constituteproject.org. Vide as well (lihat juga)1, Transparency International Zimbabwe, http://tizim.org/wpcontent/uploads/2016/05/faq6.pdf. Diaksesk pada tanggal 22 Februari 2018. 